\title{
PENTINGNYA PENGETAHUAN PERAWATAN LENSA KONTAK LUNAK BAGI PEMAKAI DI OPTIK CITRA PADANG
}

\author{
IHSAN SAUNIR ${ }^{1}$, ERMI YUSFITA ${ }^{2}$, DOLLY IMAN SURYANTA ${ }^{3}$ \\ Program Pasca Sarjana Universitas Negeri Padang ${ }^{1}$, Program Studi Refraksionis Optisien, \\ Akademi Refraksi YLPTK Padang, ${ }^{2,3}$ \\ Ihsansaunir@gmail.com¹, ermiyusfita@gmail.com²
}

\begin{abstract}
This scientific paper discusses the importance of soft contact lens care knowledge for users in Padang Citra Optics. This study aims to determine: Knowledge, care for users, the use, the impact of wearing and maintaining soft contact and also handling of the use and maintenance of soft contact lenses at Optik Citra Padang. This research design uses descriptive quantitative method. The population in this study was all patients wearing soft contact lenses at Optik Citra Padang in the period 15 July 2021-15 August 2021. Data were collected through questionnaires and research instruments using a Check List. The results showed that the respondents did not fully know the proper and correct care of soft contact lenses, this was seen as many as 24 respondents (53\%) knew the correct soft contact lens care procedure and as many as 21 respondents (47\%) did not know the treatment procedures. correct soft contact lenses, 21 respondents (47\%) understand how to properly put on and remove soft contact lenses and 24 respondents (53\%) do not understand how to properly install soft contact lenses, 20 respondents (44.40\%) know about the impact of wearing and maintaining soft contact lenses that are not up to standard and as many as 25 respondents (55.60) do not know about the impact of wearing and maintaining soft contact lenses that are not up to standard, 14 respondents (31\%) know how to handle the use and care of soft contact lenses and 31 respondents (69\%) do not know how to handle from wearing soft contact lenses. There are several suggestionsFor RO to provide information to, For opticians, it is recommended to improve the quality of eye health services to the public, for academies, it is recommended to improve the quality of education. (4) For the public, it is recommended that when wearing and caring for contact lenses, more attention should be paid to use and care for them properly so as not to cause an impact on eye health.
\end{abstract}

Keywords Soft Contact Lens, Wearers, Optics.

Abstrak: Karya tulis ilmiah ini membahas tentang Pentingnya Pengetahuan Perawatan Lensa Kontak Lunak Bagi Pemakai Di Optik Citra Padang. Rancangan penelitian ini menggunakan metode kuantitatif deskriptif. Populasi dalam penelitian ini adalah seluruh pasien pemakai lensa kontak lunak di Optik Citra Padang pada kurun waktu 15 Juli 2021-15 Agustus 2021. Data dikumpulkan melalui kuesioner dan instrument penelitian menggunakan Check List. Hasil penelitian diperoleh bahwa responden belum sepenuhnya mengetahui perawatan lensa kontak lunak yang baik dan benar, hal ini terlihat sebanyak 24 responden (53\%) mengetahui prosedur perawatan lensa kontak lunak (softlens) yang benar dan sebanyak 21 responden (47\%) tidak mengetahui prosedur perawatan lensa kontak lunak (softlens) yang benar, 21 responden (47\%) mengerti dalam memasang dan melepas lensa kontak lunak (softlens) dengan benar dan 24 responden (53\%) tidak mengerti dalam memasang lensa kontak lunak (softlens) yang benar, 20 responden (44.40\%) mengetahui tentang dampak dari pemakaian dan perawatan lensa kontak lunak (softlens) yang tidak sesuai dengan standar dan sebanyak 25 responden (55.60) tidak mengetahui tentang dampak dari pemakaian dan perawatan lensa kontak lunak (softlens) yang tidak sesuai dengan standar, 14 responden (31\%) mengetahui bagaimana penanganan dari pemakaian dan perawatan lensa kontak lunak dan 31 responden (69\%) tidak mengetahui bagaimana penanganan dari pemakaian lensa kontak lunak. Adapun kesimpulan yang di dapat dari penelitian tersebut yaitu RO hendaknya memberikan informasi kepada pasien yang mengunjungi Optik Citra Padang tentang pentingnya pengetahuan perawatan lensa kontak lunak (softlens) bagi pemakai. Kemudian Optik harus meningkatkan mutu pelayanan kesehatan mata. Selain itu akademi disarankan untuk meningkatkan mutu 
pendidikan dalam menghasilkan lulusan akademik yang professional dan siap kerja. Dan yang terakhir, bagi masyarakat harus memperhatikan cara pemakaian dan perawatan lensa kontak

Kata Kunci: Lensa Kontak Lunak, Pemakai, Optik.

\section{A. Pendahuluan}

Mata merupakan salah satu indera yang penting bagi manusia. Melalui mata manusia menyerap informasi visual yang digunakan untuk melaksanakan berbagai kegiatan. Seiring dengan perkembangan ilmu pengetahuan dan teknologi telah banyak ditemukan alternatif untuk mengatasi masalah-masalah pada organ penglihatan. Dengan kemajuan ilmu pengetahuan dan teknologi yang berkembang pesat, para ahli sudah banyak menemukan alternatif dari masing-masing masalah yang dihadapi dalam bidang perkacamataan. Selain menciptakan kacamata sebagai alat bantu penglihatan, para ahli juga menemukan alat bantu sebagai pengganti kacamata yaitu lensa kontak. Merujuk kepada Keputusan Menteri Kesehatan Republik Indonesia Nomor 572/MENKES/SK/VI/2008, lensa kontak adalah "Lensa yang dipasang menempel pada jaringan anterior kornea dan sklera untuk memperbaiki tajam penglihatan dan kosmetik".

Berdasarkan observasi yang penulis lakukan kepada pasien pemakai lensa kontak di Optik Citra Padang pasien mengeluhkan matanya terasa perih, gatal, dan merah setelah menggunakan lensa kontak. Setelah dilakukan anamnesa lanjutan diketahui bahwa pasien tidak mencuci tangan sebelum menggunakan lensa kontak lunak, merendam lensa kontak lunak dengan cairan yang sama berkali-kali, dan tidak mengikuti petunjuk pemakaian dan perawatan lensa kontak lunak yang diberikan oleh Refraksionis Optisien.

Apabila salah dalam penggunaan maupun perawatan lensa kontak lunak yang melampaui batas waktu maksimal, maka akan berakibat buruk pada mata, hal ini dikarenakan kurangnya pasokan oksigen ke mata akibat pemakaian yang terlalu lama, maka mata akan merah dan timbullah pembuluh darah yang terlihat disekitar limbus, yang mana apabila parah maka akan mengakibatkan terjadinya neovaskularisasi kornea. Pada masa sekarang banyak orang yang tidak tahu bagaimana cara pemakaian serta perawatan lensa kontak yang benar.

\section{B. Metodologi Penelitian}

Metode penelitian pada dasarnya merupakan cara ilmiah untuk mendapatkan data dengan tujuan dan kegunaan tertentu (Sugiyono, 2012:2). Dalam hal ini, lokasi penelitian terletak di Optik Citra Kota Padang. Penelitian ini dilakukan pada 15 Juli 2021 s/d 15 Agustus 2021. Populasi dan sampel dalam penelitian ini adalah seluruh pemakai lensa kontak lunak yang berjumlah 45 orang. Peneliti menggunakan kuesioner atau angket dalam mengumpulkan data yang didalamnya terdapat seperangkat daftar pertanyaan yang telah disusun sebelumnya.

\section{Hasil dan Pembahasan \\ 1. Hasil}

Hasil dari penelitian tentang pentingnya pengetahuan perawatan lensa kontak lunak bagi pemakai di Optik Citra Padang yang dilaksanakan pada tanggal 15 Juli 2021 sampai 15 Agustus 2021, dimana responden penelitian merupakan pasien di Optik Citra Padang yang berjumlah 45 orang yang terdiri dari 5 Orang laki-laki dan 40 Orang perempuan yang berusia 18 tahun keatas.

Adapun Pengetahuan Perawatan Lensa Kontak Lunak (Softlens) Bagi Pemakai di optic citra padang dapat di lihat pada tabel berikut:

\begin{tabular}{|l|l|l|}
\hline $\begin{array}{l}\text { Mengetahui Perawatan Lensa Kontak Lunak (Softlens) } \\
\text { yang Benar }\end{array}$ & Frekuensi & Persentase \\
\hline Ya & $\mathbf{3 3}$ & $\mathbf{7 2 \%}$ \\
\hline Tidak & $\mathbf{1 2}$ & $\mathbf{2 8 \%}$ \\
\hline Jumlah & $\mathbf{4 5}$ orang & $\mathbf{1 0 0 \%}$ \\
\hline 446 & \multicolumn{2}{|c|}{ E-ISSN: 2657-0300 } \\
\hline
\end{tabular}


Berdasarkan tabel 1 dapat diketahui bahwa 33 responden (72\%) mengetahui dan sudah memahami prosedur perawatan lensa kontak lunak (softlens) yang benar dan sebanyak 12 responden (28\%) tidak mengetahui prosedur perawatan lensa kontak lunak (softlens) yang benar. Dari kasus itu dapat disimpulkan bahwa sebagian reponden belum mengetahui prosedur perawatan lensa kontak lunak (softlens) yang benar.

Pemakai yang Mengetahui Cara Pemakaian dan Perawatan Lensa Kontak Lunak (Softlens) yang Benar dapat di lihat pada tabel berikut ini:

\begin{tabular}{|l|l|l|}
\hline $\begin{array}{l}\text { Mengetahui Cara Pemakaian dan Perawatan Lensa } \\
\text { Kontak Lunak (Softlens) Yang Benar }\end{array}$ & Frekuensi & Persentase \\
\hline Ya & 27 & $\mathbf{6 0 \%}$ \\
\hline Tidak & 18 & $\mathbf{4 0 \%}$ \\
\hline Jumlah & $\mathbf{4 5}$ orang & $\mathbf{1 0 0 \%}$ \\
\hline
\end{tabular}

Berdasarkan tabel 2 dapat diketahui bahwa 27 responden (60\%) mengetahui cara pemakaian dan perawatan lensa kontak lunak (softlens) dengan benar dan 18 responden (40\%) tidak mengetahui cara pemakaian dan perawatan lensa kontak lunak (softlens) yang benar. Dari kasus diatas dapat disimpulkan bahwa sebagian besar responden belum mengetahui cara pemakaian dan perawatan lensa kontak lunak yang benar bagi kesehatan mata.

Adapun Dampak dari Pemakaian dan Perawatan Lensa Kontak Lunak (Softlens) Yang Tidak Sesuai Standar dapat dilihat pada tabel berikut:

\begin{tabular}{|l|l|l|}
\hline $\begin{array}{l}\text { Mengetahui Dampak dari Pemakaian dan Perawatan } \\
\text { Lensa Kontak Lunak (Softlens) Yang Tidak Sesuai Standar }\end{array}$ & Frekuensi & Persentase \\
\hline Ya & $\mathbf{3 4}$ & $\mathbf{7 6 \%}$ \\
\hline Tidak & 11 & $\mathbf{2 4 \%}$ \\
\hline Jumlah & $\mathbf{4 5}$ orang & $\mathbf{1 0 0 \%}$ \\
\hline
\end{tabular}

Dari tabel diatas dapat diketahui bahwa 34 responden (76\%) mengetahui dampak yang ditimbulkan dari pemakaian dan perawatan lensa kontak lunak (softlens) yang tidak sesuai standar dan 11 responden (24\%) tidak mengetahui dampak yang ditimbulkan dari pemakaian dan perawatan lensa kontak lunak (softlens) yang tidak sesuai standar.

Dan yang terakhir adalah jumlah responden terhadap Penanganan dari Pemakaian dan Perawatan Lensa Kontak Lunak (Softlens)

\begin{tabular}{|l|l|l|}
\hline $\begin{array}{l}\text { Mengetahui Penanganan dari Pemakaian dan Perawatan } \\
\text { Lensa Kontak Lunak (Softlens) }\end{array}$ & $\begin{array}{l}\text { Frekuens } \\
\text { i }\end{array}$ & Persentase \\
\hline Ya & 27 & $\mathbf{6 0 \%}$ \\
\hline Tidak & 18 & $\mathbf{4 0 \%}$ \\
\hline Jumlah & $\mathbf{4 5}$ orang & $\mathbf{1 0 0 \%}$ \\
\hline
\end{tabular}

Dari tabel diatas dapat diketahui bahwa 27 responden (60\%) mengetahui bagaimana penanganan dari pemakaian dan perawatan lensa kontak lunak (softlens) dan 18 responden (40\%) tidak mengetahui bagaimana penanganan dari pemakaian dan perawatan lensa kontak lunak (softlens). Dari kasus diatas dapat disimpulkan bahwa sebagian responden belum mengetahui bagaimana penanganan dari pemakaian dan perawatan lensa kontak lunak.

\section{Pembahasan}

Berdasarkan kuesioner yang telah dibagikan kepada responden tentang cara pemakaian dan perawatan lensa kontak lunak (softlens) yang benar bagi kesehatan mata dapat diketahui bahwa banyak responden yang belum mengetahui tentang cara pemakaian dan perawatan lensa kontak lunak (softlens) yang benar bagi kesehatan mata. Kemudian tentang cara pemakaian dan perawatan lensa kontak lunak (softlens) yang benar bagi kesehatan mata dapat diketahui bahwa banyak responden yang belum mengetahui tentang cara pemakaian dan perawatan lensa kontak lunak (softlens) yang benar bagi kesehatan mata, salah satu contoh kasus bahwa responden belum mengetahui tentang cara pemakaian dan perawatan lensa kontak lunak bagi E-ISSN: 2657-0300 Lembaga Penelitian dan Penerbitan Hasil Penelitian Ensiklopedia $\quad 447$ P-ISSN: 2657-0319 
kesehatan mata yaitu peneliti menemukan banyak responden yang tidak mengerti bagaimana cara memasang dan melepas lensa kontak lunak dengan baik serta tidak memahami apa yang menyebabkan lensa kontak lunak tidak nyaman saat dipakai.

Dari pemakaian dan perawatan lensa kontak lunak (softlens) yang tidak sesuai dengan standar dapat diketahui bahwa banyak responden yang belum mengetahui tentang dampak dari pemakaian serta perawatan lensa kontak lunak (softlens) yang tidak sesuai dengan standar, salah satu contoh kasus untuk mempertegas hasil penelitian ini yaitu banyak responden yang tidak mengetahui bahwa pemakaian lensa kontak lunak (softlens) yang terlalu lama dapat menimbulkan gangguan pada mata dan merasakan perih serta sakit pada mata ketika memakai lensa kontak lunak (softlens).

Tentang penanganan dari pemakaian dan perawatan lensa kontak lunak (softlens) dapat diketahui banyak responden yang belum memahami betul tentang penanganan dari pemakaian dan perawatan lensa kontak lunak (softlens). Salah satu contoh kasus untuk mempertegas dan memperjelas hasil penelitian ini yaitu banyak responden yang tidak selalu mambuang cairan perendam lensa kontak lunak (solution) setelah dipakai dan menggantinya dengan cairan yang baru serta banyak responden yang tidak mengetahui berapa lama waktu minimal perendaman lensa kontak lunak (softlens).

\section{Penutup}

Berdasarkan hasil penelitian di atas dapat ditarik kesimpulan, yaitu: 1. 72\% responden pemakai lensa kontak lunak (softlens) di Optik Citra Padang mempunyai pengetahuan tentang perawatan lensa kontak lunak (softlens). 2. 40\% responden pemakai lensa kontak lunak (softlens) di Optik Citra Padang tidak mengetahui cara pemakaian dan perawatan lensa kontak lunak (softlens) yang benar. 3. 76\% responden tidak mengetahui dampak dari pemakaian dan perawatan lensa kontak lunak (softlens) yang tidak sesuai standar. 4. 60\% responden pemakai lensa kontak lunak (softlens) di Optik Citra Padang tidak mengetahui penanganan dari pemakaian dan perawatan lensa kontak lunak (softlens).

\section{Daftar Pustaka}

Akademi Refraksi Optisi. 2013. Bahan Ajar Lensa Kontak Lunak Padang: ARO Padang DEPKES, Tahun 2002. No 544/MENKES/XI/2002. Registrasi dan izin kerja Refraksionis Optisien.

DEPKES RI.2002 PERMENKES, NO 1424/MENKES/SK XI/2002. Pedoman Penyelenggara Optikal

Jakarta Eye Center. 2019. Lensa Kontak. [online]. Tersedia : https://jec.co.id/id/service/page/26/52/lensa-kontak. [18 Maret 2021]

Kemenkes RI. 2008. Keputusan Menteri Kesehatan Republik Indonesia Nomor 572/MENKES/SK/VI/2008 Tentang Standar Profesi Refraksionis Optisien. [online]. Tersedia : http://pelayanan.jakarta.go.id/download/regulasi/keputusan-menterikesehatan-republik-indonesia-nomor-572-tentang-standar-profesi-refraksionisoptisien.pdf. [20 April 2021]

Mannis, M. J., Krla Z., Cleusa, C. G., Newton, K. J. 2013. Contact Lenses in

Rinaldi, 2008. Lensa Kontak. [online]. Tersedia: https://klinikmatanusantara.com / . [di akses tanggal 18 Maret 2021]

Rizka. 2016. GambaranTingkat Pengetahuan Pelajar Putri Tentang penggunaan Lensa Kontak di SMK Nusantara 1 Ciputat Kota Tangerang Selatan Tahun 2015. Fakultas Kedokteran Dan Ilmu Kesehatan Program Studi Ilmu Keperawatan Universitas Islam Negri Syarif Hidayatullah Jakarta.

Rumpakis JMB, 2010. New data on contact lens dropouts: an international perspective. Review of Optometry. [online] Tersedia: http://www.revoptom.com/content/d/contact_lenses_and_solutions/c/18929/ [di Akses tanggal 16 Maret 2021]. 